\author{
Notaire \\ e-ISSN: 2655-9404 \\ p-ISSN: 2721-8376 \\ Vol. 4 No. 2, Juni 2021 \\ DOI: $10.20473 /$ ntr.v4i2.26120
}

Article history: Submitted 27 March 2021; Accepted 7 May 2021; Available online 1 June 2021.

\title{
Keabsahan Klausula Perpanjangan Periode dalam Restrukturisasi Kredit Akibat Pandemi Covid-19
}

\author{
Tamara Teguh \\ tamara.teguh-2018@fh.unair.ac.id \\ Universitas Airlangga
}

\begin{abstract}
The Corona Virus Disease 2019 (COVID-19) outbreak was determined by the President as a nonnatural disaster through Presidential Decree Number 12 of 2020 concerning the Designation of NonNatural Disaster for the Spread of Corona Virus Disease 2019 (COVID-19) as a National Disaster. Its rapid spread has an impact on all aspects of human life, especially in the economic sector, many business actors have suffered losses and a number of banks are experiencing credit risk, which debtors or customers are unable to make credit installments on the pretext of being affected by the pandemic. The Presidential Decree cannot automatically cancel existing agreements, so that the Government makes policies in order to stimulate economic growth. This policy was issued by the Financial Services Authority through Regulation of the Financial Services Authority of the Republic of Indonesia Number 11/POJK.03/2020 concerning National Economic Stimulus as a Countercyclical Policy on the Impact of the Spread of Corona Virus Disease 2019 which has been extended by the Financial Services Authority Regulation of the Republic of Indonesia Number 48/POJK.03/2020 as an effort to avoid default. The debtor is given loan repayment relief at the Bank or Leasing with terms determined by the Bank. This payment relief is known as credit restructuring, which there is a renegotiation process to change existing loans. One of the changes in the agreement is by rescheduling, namely extending the installment payment period. Keywords: COVID-19 Disease Outbreak; Credit Restructuring; Rescheduling.
\end{abstract}

\section{Abstrak}

Wabah penyakit Corona Virus Disease 2019 (COVID-19) ditetapkan oleh Presiden sebagai bencana non alam melalui Keputusan Presiden Republik Indonesia Nomor 12 Tahun 2020 Tentang Penetapan Bencana Non Alam Penyebaran Corona Virus Disease 2019 (COVID-19) Sebagai Bencana Nasional. Penyebarannya yang begitu pesat berdampak pada segala aspek kehidupan manusia terutama di bidang ekonomi, banyak pelaku usaha yang mengalami kerugian dan sejumlah perbankan mengalami risiko kredit, dimana debitur atau nasabah tidak mampu untuk melakukan pembayaran cicilan kredit dengan dalih terkena dampak pandemi. Dengan adanya Keputusan Presiden itu tidak dapat serta merta membatalkan perjanjian yang sudah ada, sehingga Pemerintah membuat kebijakan dalam rangka menstimulus pertumbuhan ekonomi. Kebijakan tersebut dikeluarkan oleh Otoritas Jasa Keuangan melalui Peraturan Otoritas Jasa Keuangan Republik Indonesia Nomor 11/ POJK.03/2020 Tentang Stimulus Perekonomian Nasional Sebagai Kebijakan Countercyclical Dampak Penyebaran Corona Virus Disease 2019 yang telah diperpanjang dengan Peraturan Otoritas Jasa Keuangan Republik Indonesia Nomor 48/POJK.03/2020 sebagai upaya agar tidak terjadinya wanprestasi. Debitur diberikan keringanan pembayaran cicilan pinjaman di Bank atau Leasing dengan persyaratan-persyaratan yang ditentukan oleh Bank. Keringanan pembayaran ini dikenal dengan restrukturisasi kredit, dimana terdapat proses renegosiasi atau negosiasi ulang untuk merubah perjanjian kredit yang sudah ada. Perubahan perjanjian tersebut salah satunya ialah dengan penjadwalan kembali atau rescheduling, yaitu memperpanjang periode pembayaran cicilan.

Kata Kunci: Wabah Penyakit COVID-19; Restrukturisasi Kredit; Penjadwalan Kembali. 


\section{Pendahuluan}

Awal tahun 2020 dunia digemparkan dengan adanya sebuah virus yang datang dari Kota Wuhan, China bernama virus corona atau Corona Virus Disease 2019 (yang selanjutnya disebut COVID-19). Virus ini memberikan dampak yang sangat besar bagi seluruh dunia termasuk Indonesia. Pada tanggal 11 Maret 2020, WHO (World Health Organization) kemudian mengumumkan status pandemi global untuk virus tersebut. Guna menanggulangi penyebaran virus ini Pemerintah menghimbau masyarakat untuk melakukan social distancing, yang mana diganti dengan istilah physical distancing, melakukan pembatasan social berskala besar, serta menaati protokol kesehatan, seperti memakai masker, mencuci tangan, menjaga jarak, menjauhi kerumunan dan mengurangi mobilitas. Kebijakan tersebut disebut 5M. Imbauan Pemerintah ini diikuti dengan dikeluarkannya beberapa peraturan, yakni Peraturan Pemerintah Republik Indonesia Nomor 21 Tahun 2020 Tentang Pembatasan Sosial Berskala Besar Dalam Rangka Percepatan Penanganan Corona Virus Disease 2019 (COVID-19), Keputusan Presiden Republik Indonesia Nomor 11 Tahun 2020 Tentang Penetapan Kedaruratan Kesehatan Masyarakat Corona Virus Disease 2019 (COVID-19), Peraturan Menteri Kesehatan Republik Indonesia Nomor 9 Tahun 2020 Tentang Pedoman Pembatasan Sosial Berskala Besar Dalam Rangka Percepatan Penanganan Corona Virus Disease 2019 (COVID-19). Selain itu, dikeluarkan pula Keputusan Presiden Republik Indonesia Nomor 12 Tahun 2020 Tentang Penetapan Bencana Non Alam Penyebaran Corona Virus Disease 2019 (COVID-19) Sebagai Bencana Nasional.

Namun disisi lain, kebijakan tersebut memberatkan bagi sektor perekonomian karena dengan adanya kebijakan ini menyebabkan aktivitas masyarakat di luar rumah berkurang, sehingga tempat hiburan, pariwisata, pusat perbelanjaan, restoran maupun perkantoran mengalami penurunan yang berdampak pada pengusaha maupun tenaga kerjanya. Pelaku usaha yang terikat dalam kontrak bisnis, pada saat pandemi seperti ini merasa dirugikan karena kegiatan ekonomi yang ditargetkan untuk mendapatkan keuntungan, justru sebaliknya. Sehingga banyak pula yang tidak dapat melanjutkan aktivitas bisnisnya. Disisi lain dalam dunia kredit perbankan, 
banyak pula debitur yang tidak bisa melunasi utangnya karena keadaan ekonomi ditengah pandemi seperti ini. Oleh karena itu, Otoritas Jasa Keuangan (selanjutnya disebut OJK) mengeluarkan Peraturan Otoritas Jasa Keuangan Republik Indonesia Nomor 11/POJK.03/2020 Tahun 2020 Tentang Stimulus Perekonomian Nasional Sebagai Kebijakan Countercyclical Penyebaran Corona Virus Disease 2019 (COVID-19) yang telah diperpanjang dengan POJK Nomor 48 /POJK.03/2020.

Berdasarkan POJK tersebut, untuk mendukung atau menstimulus pertumbuhan ekonomi yang ada dalam hal ini Bank dapat memberikan restrukturisasi kredit atau pembiayaan kepada debitur, yang mana debitur dimaksud adalah debitur yang terkena dampak penyebaran COVID-19 termasuk debitur usaha mikro, kecil dan menengah, baik secara langsung maupun tidak langsung mengalami kesulitan dalam pemenuhan kewajibannya kepada pihak Bank, meliputi bank umum konvensional termasuk unit usaha syariah, bank umum syariah, bank perkreditan rakyat, bank pembiayaan rakyat syariah, yang melaksanakan kegiatan usaha secara konvensional atau berdasarkan prinsip syariah. Jenis-jenis usaha yang dapat diberikan stimulus adalah yang bergerak pada sektor ekonomi antara lain pariwisata, transportasi, perhotelan, perdagangan, pengolahan, pertanian, dan pertambangan.

Pada dasarnya restrukturisasi kredit sebenarnya merupakan hal yang umum dalam hubungan hukum pinjam meminjam. Restrukturisasi kredit ini melahirkan hubungan hukum yang timbul dari perjanjian saja. ${ }^{1}$ Maka dengan adanya restrukturisasi kredit, harus adanya kesepakatan antara pemberi pinjaman dalam hal ini adalah Bank atau leasing dan penerima pinjaman atau debitur untuk melakukan perubahan atas perjanjian kredit tersebut. Renegosiasi untuk merubah perjanjian yang dapat dilakukan oleh para pihak ini tentu harus memperhatikan pertimbangan, salah satunya pertimbangan ekonomi yang terjadi saat ini. Sehingga perlu adanya kesepakatan para pihak untuk melakukan renegosiasi, gunanya agar tidak saling merugikan para pihak karena COVID-19 ini dapat dikualifikasikan sebagai force majeur.

${ }^{1}$ Edi Putra Tje'Aman, Kredit PerBankan Suatu Tinjauan Yuridis (Liberty 1986).[17]. 
Sebagaimana ditentukan dalam ketentuan Pasal 1245 BW yang menyatakan bahwa "Tidak ada penggantian biaya, kerugian dan bunga, bila karena keadaan memaksa atau karena hal yang terjadi secara kebetulan, debitur terhalang untuk memberikan atau berbuat sesuatu yang diwajibkan, atau melakukan suatu perbuatan yang terlarang baginya".

Keadaan memaksa yang dimaksud dalam ketentuan Pasal 1245 BW tersebut adalah force majeure. Beberapa unsur yang dapat menimbulkan keadaan force majeure adalah: ${ }^{2}$

1. Adanya kejadian yang tidak terduga;

2. Adanya halangan yang menyebabkan suatu prestasi tidak mungkin dilaksanakan;

3. Ketidakmampuan tersebut tidak disebabkan oleh kesalahan debitur;

4. Ketidakmampuan tersebut tidak dapat dibebankan risiko kepada debitur.

Apabila dilihat dari sifatnya, force majeure dapat dibagi menjadi dua, yaitu force majeure absolut dan force majeure relatif. Force majeure absolut merupakan keadaan dimana pelaksanaan prestasi tidak mungkin dilakukan para pihak atau kewajiban benar-benar tidak dapat dilaksanakan seluruhnya. Sedangkan force majeure relatif merupakan keadaan dimana pelaksanaan prestasi yang masih mungkin dilakukan atau dengan kata lain suatu perjanjian masih mungkin untuk dilaksanakan.

Berdasarkan pengetian tersebut, maka COVID-19 yang merupakan bencana nasional ini dapat dikualifikasikan sebagai force majeure relatif atau sementara. Dikatakan sebagai force majeure relatif atau sementara karena pandemi COVID-19 dapat segera berakhir mengingat adanya penemuan vaksin yang sudah diuji coba maupun yang sedang diuji coba. Dengan dikeluarkannya POJK No. 11/2020 yang telah diperpanjang dengan POJK No. 48/2020, maka peraturan ini dapat digunakan bagi para pihak yang terikat suatu perjanjian untuk melakukan renegosiasi. Klausula tentang force majeure yang ada dalam perjanjian kredit dapat dilakukan restrukturirasi kredit dengan bentuk renegosiasi antara para pihak, dimana umumnya pihak Bank yang menawarkan penjadwalan ulang terkait 
pelunasan pembayaran dengan memperpanjang periode pembayaran. Selain itu, pihak Bank juga harus mengetahui bahwa debiturnya memiliki itikad baik dalam melunasi utangnya.

Disisi lain adanya peraturan yang dapat digunakan untuk melakukan perubahan perjanjian, yaitu Keputusan Presiden Republik Indonesia Nomor 12 Tahun 2020 Tentang Penetapan Bencana Non Alam Penyebaran Corona Virus Disease 2019 (COVID-19) Sebagai Bencana Nasional yang selanjutnya disebut Keppres Nomor 12 Tahun 2020. Dengan dikeluarkannya Keputusan Presiden ini tidak dapat secara otomatis atau serta merta dijadikan dasar untuk membatalkan atau menyimpangi kontrak-kontrak bisnis yang sudah dibuat sebelum keluarnya Keputusan Presiden ini, namun dengan adanya Keputusan Presiden tersebut dapat dijadikan sebagai landasan untuk menegosiasikan ulang kontrak-kontrak bisnis yang sudah ada, dengan tetap mengindahkan aturan yang ada. Karena Keputusan Presiden itu bersifat pemberitahuan tentang terjadinya force majeur maka dapat dijadikan sebagai landasan untuk renegosiasi, dimana renegosiasi dengan tetap berpedoman pada asas-asas umum perjanjian, salah satunya pada ketentuan Pasal 1338 BW yang menyatakan bahwa, "Semua perjanjian yang dibuat secara sah berlaku sebagai undang-undang bagi mereka yang membuatnya". Sehingga tidak dapat secara otomatis Keputusan Presiden ini membatalkan kontrak-kontrak yang sudah ada.

\section{Metode Penelitian}

Penelitian ini menggunakan metode penelitian yuridis normatif. Pendekatan yang digunakan dalam penelitian ini adalah pendekatan peraturan perundangundangan (statute approach) dan pendekatan konseptual (conceptual approach).

\section{Syarat Dilakukan Restrukturisasi Kredit Dalam Renegoisasi Perjanjian Kredit} Saat Pandemi COVID-19 Berdasarkan Keppres Nomor 12 Tahun 2020

Perkembangan penyebaran COVID-19 di Indonesia melambung begitu cepat, data yang diperoleh dari COVID19.go.id pertanggal 28 September 2020 terdapat 278.722 kasus, yang mana terdiri dari 61.378 kasus aktif, 206.870 sembuh 
dan 10.473 meninggal dunia. Melihat perkembangan penyebaran COVID-19 yang begitu pesat, COVID-19 dapat dikualifikasikan sebagai sebuah wabah penyakit menular, sebagaimana didefinisikan pada ketentuan umum Pasal huruf a Undang-Undang Republik Indonesia Nomor 4 Tahun 1984 Tentang Wabah Penyakit Menular dikatakan bahwa, "Wabah penyakit menular yang selanjutnya disebut wabah adalah kejadian berjangkitnya suatu penyakit menular dalam masyarakat yang jumlah penderitanya meningkat secara nyata melebihi dari pada keadaan yang lazim pada waktu dan daerah tertentu serta dapat menimbulkan malapetaka." Kemudian huruf b berbunyi, "Sumber penyakit adalah manusia, hewan, tumbuhan, dan benda-benda yang mengandung dan/atau tercemar bibit penyakit, serta yang dapat menimbulkan wabah".

Menurut Undang-Undang Republik Indonesia Nomor 24 Tahun 2007 Tentang Penanggulangan Bencana, yang dimaksud bencana terdiri dari bencana alam, non alam dan sosial. Bencana non alam berdasarkan Pasal 1 angka 3 ketentuan umum Undang-Undang Republik Indonesia Nomor 24 Tahun 2007 memberi pengertian bahwa, "Bencana non alam adalah bencana yang diakibatkan oleh peristiwa atau rangkaian peristiwa non alam yang antara lain berupa gagal teknologi, gagal modernisasi, epidemi, dan wabah penyakit". Dalam hal ini penyakit COVID-19 termasuk bencana non alam dan bestatus sebagai keadaan darurat bencana. Pada ketentuan Pasal 1 Angka 19 Undang-Undang Republik Indonesia Nomor 24 Tahun 2007 menentukan, "Status keadaan darurat bencana adalah suatu keadaan yang ditetapkan oleh Pemerintah untuk jangka waktu tertentu atas dasar rekomendasi Badan yang diberi tugas untuk menanggulangi bencana".

Selanjutnya pada ketentuan Pasal 51 disebutkan:

1. Penetapan status darurat bencana dilaksanakan oleh pemerintah sesuai dengan skala bencana;

2. Penetapan sebagaimana dimaksud pada ayat (1) untuk skala nasional dilakukan oleh Presiden, skala provinsi dilakukan oleh gubernur, dan skala kabupaten/kota dilakukan oleh bupati/walikota. 
Dengan demikian merujuk pada Pasal 7 ayat (1) huruf c Undang-Undang Nomor 24 Tahun 2007, di mana penetapan status dan tingkatan bencana nasional dan daerah merupakan wewenang pemerintah dalam penyelenggaraan penanggulangan bencana. Penetapan status darurat bencana untuk skala nasional dilakukan oleh Presiden, skala provinsi dilakukan oleh Gubernur, dan skala kabupaten/kota dilakukan oleh Bupati/Walikota. Penetapan penyebaran COVID-19 sebagai bencana nasional dapat dilihat pada Keputusan Presiden Nomor 12 Tahun 2020 tentang Penetapan Bencana Nonalam Penyebaran Corona Virus Disease 2019 (COVID-19) sebagai Bencana Nasional yang mulai berlaku sejak 13 April 2020.

Selain itu, WHO juga telah menyatakan COVID-19 sebagai Global Pandemic pada tanggal 11 Maret 2020. Oleh karenanya, berdasarkan pertimbangan di atas, maka pemerintah perlu menetapkan Keputusan Presiden Nomor 12 Tahun 2020 ini. Pandemi COVID-19 telah mengganggu berbagai sektor terutama dalam melaksanakan perjanjian. Oleh karena adanya pandemi COVID-19, banyak permasalahan dalam melaksanakan suatu perjanjian disatu sisi debitur menganggap bahwa kreditur yang tidak dapat melaksanakan prestasinya sehingga dikatakan wanprestasi, namun disisi lain kreditur menyangkal bahwa karena adanya pandemi COVID-19 ini dijadikan alasan force majeure atau keadaan memaksa (keadaan kahar).

Dengan dikeluarkannya Keputusan Presiden Nomor 12 Tahun 2020, COVID-19 dianggap sebagai bencana non alam, maka oleh sebagian orang yang terikat dalam suatu hubungan kontraktual menganggap bahwa tidak dapat dipenuhinya suatu prestasi tersebut adalah karena force majeure.

Aturan-aturan terkait force majeure secara umum terdapat di dalam BW pada ketentuan Pasal 1244 dan 1245 BW, meskipun diatur di dalam BW, namun tidak diberikan definisi secara eksplisit mengenai apa itu force majeure. Dalam ketentuan Pasal 1244 BW menyatakan bahwa seseorang tidak dapat dituntut ganti kerugian karena apabila satu pihak tidak dapat memenuhi kewajibannya bukan karena kelalaian yang disengaja atau bukan karena itikad buruknya, maka seseorang itu 
dapat terbebas dari pembayaran ganti kerugian. Selanjutnya, dalam ketentuan Pasal 1245 BW menyatakan bahwa seseorang tidak dapat dituntut ganti kerugian karena adanya keadaan memaksa atau karena hal yang terjadi secara kebetulan. Berdasarkan teori, terdapat 2 jenis force majeur, yaitu: ${ }^{3}$

1. force majeur absolut; dan

2. force majeur relatif.

Force majeure absolut terjadi apabila kewajiban benar-benar tidak dapat dilaksanakan seluruhnya, misalnya ketika objek benda hancur karena bencana alam. Dalam hal ini pemenuhan prestasi tidak mungkin dilaksanakan oleh siapapun juga atau oleh setiap orang. ${ }^{4}$ Force majeure relatif terjadi ketika suatu perjanjian masih mungkin untuk dilaksanakan namun dengan pengorbanan atau biaya yang sangat besar dari pihak debitur, misalnya harga bahan baku impor menjadi sangat tinggi atau pemerintah tiba-tiba melarang membawa barang objek perjanjian keluar dari suatu pelabuhan. ${ }^{5}$

Agar debitur dapat mengemukakan alasan force majeur harus dipenuhi tiga persyaratan: ${ }^{6}$

1. Ia harus membuktikan bahwa ia tidak bersalah;

2. Ia tidak dapat memenuhi kewajibannya secara lain; dan

3. Ia tidak menanggung risiko, baik menurut ketentuan undang-undang maupun perjanjian atau karena itikad baik harus menanggung risiko.

Dengan dikeluarkannya Keputusan Presiden Nomor 12 Tahun 2020, maka Keputusan Presiden ini sebagai dasar hukum force majeure. Dalam poin Kesatu Keputusan Presiden Nomor 12 Tahun 2020 disebutkan bahwa menyatakan bencana non alam yang diakibatkan oleh penyebaran COVID-19 sebagai bencana nasional. Pernyataan tersebut menegaskan bahwa COVID-19 adalah bencana non alam, sehingga dapat dikatakan bahwa COVID-19 sebagai force majeure. Namun, dengan

\footnotetext{
${ }^{3}$ Subekti, Pokok-pokok Hukum Perdata (Intermasa 1985).[150].

${ }^{4}$ Mariam Darus Badrulzaman, Kitab Undang-Undang Hukum Perdata Buku III Hukum Perikatan Dengan Penjelasan (Alumni 1996).[39].

${ }^{5}$ ibid.

${ }^{6}$ ibid.
} 
dikeluarkannya Keppres Nomor 12 Tahun 2020 tidak serta merta mengindahkan debitur untuk dapat menunda atau bahkan membatalkan perjanjian.

Dengan demikian akibat hukum pandemi COVID-19 dikategorikan sebagai force majeure yang bersifat relatif ialah bahwa pandemi ini tidak dapat dijadikan alasan bagi para pihak untuk membatalkan kontrak. Akan tetapi, force majeure relatif ini hanya menunda atau menangguhkan kewajiban kontaktual debitur untuk sementara waktu. Suatu perjanjian tetap sah dan mengikat para pihak, sedangkan keadaan atau peristiwa pandemi COVID-19 ini hanya bersifat sementara, sehingga dapat menunda pemenuhan kewajiban debitur kepada kreditur dan hal ini tidak menghapuskan kewajiban debitur kepada kreditur. Oleh karena itu demi melindungi kepentingan para pihak, maka renegosiasi kontrak untuk perubahan perjanjian perlu dilakukan, dimana para pihak dapat bernegosiasi ulang atau mengatur kembali aturan-aturan yang tidak memadai lagi guna menyikapi keadaan baru ini.

Renegosiasi dalam perjanjian kredit dikenal dengan restrukturisasi kredit. Restrukturisasi merupakan keringanan pembayaran cicilan pinjaman di Bank atau Leasing, mengingat di masa pandemi COVID-19 ini banyak debitur yang keberatan untuk membayar kredit atau tidak bisa melanjutkan cicilan pinjaman di Bank, sehingga Bank mengeluarkan kebijakan restrukturisasi perjanjian kredit agar para pihak tetap dapat memenuhi kewajiban meskipun tidak seperti yang diperjanjikan diawal. Keberatan di bidang perekonomian yang dialami debitur di masa pandemi ini tentu sangat berpengaruh dengan kualitas pembayaran guna pemenuhan kewajiban tersebut yang kemudian melalui POJK No. 11/2020 yang telah diperpanjang dengan POJK No. 48/2020 pihak Bank memberikan kesempatan bagi debitur yang terkena dampak penyebaran COVID-19 terutama usaha kecil dengan nilai pinjaman dibawah sepuluh miliar rupiah, usaha mikro, kecil dan menengah, pekerja harian, nelayan, ojek online dan usaha kecil lainnya untuk mengajukan keringanan kredit. Restrukturisasi bukanlah penghapusan utang, namun memberikan keringanan dalam membayar cicilan utang yang tetap harus dibayar. Jadi, dengan kata lain utang debitur tersebut masih tetap ada. 
Berdasarkan website resmi Otoritas Jasa Keuangan (OJK), prosedur restrukturisasi kredit dalam masa pandemi ini dapat dilakukan tanpa perlu datang langsung ke kantor yang bersangkutan, tetapi hanya dengan menghubungi Bank atau Leasing dimana tempat debitur meminjam, mengingat meningkatnya kasus penyebaran COVID-19 sehingga harus tetap waspada apabila datang langsung ke kantor yang bersangkutan dengan mematuhi protokol kesehatan yang ada. Tedapat berbagai cara untuk menghubungi kantor Bank atau Leasing tersebut, misalnya melalui telepon, email, whatsapp, maupun sarana komunikasi digital lainnya. Selanjutnya, pengumuman Bank atau Leasing yang memberikan keringanan dapat dilihat di website atau media sosial resmi OJK.

Di samping itu, terkait persyaratan untuk dilakukannya restrukturisasi kredit dalam masa pandemi ini tentu dengan tetap bepedoman pada asas pokok hukum perjanjian dalam BW, diantaranya asas konsesualisme atau asas kesepakatan, asas kebebasan berkontrak, asas itikad baik dan asas proporsionalitas. Dalam restrukturisasi kredit pertama-tama, antara debitur dan kreditur, yang dalam hal ini pihak Bank harus memenuhi syarat sepakat terlebih dahulu. Kesepakatan atau kesamaan kehendak dari para pihak merupakan syarat mutlak untuk menjamin keabsahan suatu perjanjian.

Sama seperti syarat umum dalam perjanjian, restrukturisasi kredit melalui renegosiasi juga harus memperhatikan syarat sahnya perjanjian, dimana menurut ketentuan Pasal 1320 BW terdapat empat syarat yaitu meliputi, pertama, kesepakatan, artinya antara kreditur dan debitur harus ada kata sepakat dan setuju untuk mengadakan renegosiasi untuk perubahan perjanjian kredit tersebut dan apa saja yang akan diperjanjikan tersebut. Kedua, kecakapan, dimana kreditur atau Bank dan debitur secara hukum memenuhi kriteria sebagai subyek hukum yang cakap atau dapat melakukan perbuatan hukum. Ketiga, obyek tertentu, dimana di dalam suatu perubahan perjanjian kredit ini telah ditentukan hal apa saja yang akan diubah. Keempat, sebab yang diperbolehkan, artinya suatu perjanjian yang dibuat itu tidak boleh bertentangan dengan peraturan perundang-undangan yang berlaku, dimana ditegaskan pada ketentuan Pasal 1337 BW bahwa yang dimaksud 
dengan sebab yang diperbolehkan adalah tidak bertentangan dengan kepatutan, ketertiban umum dan peraturan perundang-undangan.

Kontrak yang ideal seharusnya mampu mewadahi pertukaran kepentingan para pihak secara fair dan adil (proporsional) pada setiap fase atau tahapan kontrak. ${ }^{7}$ Pertukaran kepentingan tersebut sebagai salah satu tahapan penting mengingat keadilan bagi kedua belah pihak adalah tujuan dari dibuatnya suatu perjanjian. Oleh karena itu, perlu dicermati adanya fase penting yang harus dilalui para pihak dalam proses pembentukan kontrak, yaitu negosiasi. Negosiasi dalam kontrak komersial merupakan perwujudan penerapan asas proporsional menuju tahapan pembentukan kontrak. ${ }^{8}$ Negosiasi merupakan tahapan yang sangat penting dalam membentuk suatu kontrak atau perjanjian, dimana negosiasi bertujuan untuk mengetahui apa yang diinginkan kedua belah pihak sampai hingga akhirnya tercapai kesepakatan yang memuat hak dan kewajiban bagi para pihak. Setelah tercapainya kesepakatan, selanjutnya hasil akhir dari kesepakatan para pihak tersebut disusun dalam bentuk kontrak, yang kemudian kontrak yang disepakati ini akan mengikat para pihak. Segala upaya dan tahapan negoisasi yang dilalui pada akhirnya akan bermuara pada bingkai kontrak yang melahirkan keterikatan kontraktual. ${ }^{9}$

Dalam restrukturisasi kredit, selain adanya negosiasi, kesepakatan serta keadilan atau proporsional, juga harus memperhatikan asas itikad baik atau good faith, dimana harus adanya kejujuran antar para pihak dan kepercayaan kedua belah pihak serta tidak ada niat untuk menipu atau merugikan pihak yang lain atas perjanjian yang telah mereka sepakati. Asas ini termuat dalam ketentuan Pasal 1883 ayat (3) BW yang berbunyi, "suatu perjanjian harus dilaksanakan dengan itikad baik".

Hingga tanggal 7 September 2020, menurut data OJK yang diunggah pada website resminya kurang lebih ada 100 Bank yang telah melakukan upaya restrukturisasi kredit kepada 7,38 juta nasabah senilai 884,46 triliun rupiah.

${ }^{7}$ Agus Yudha Hernoko, Hukum Perjanjian Asas Proporsionalitas Dalam Kontrak Komersial (Kencana 2014).[148].

8 ibid.

${ }^{9}$ ibid.[150-151]. 
Kebijakan mengenai restrukturisasi ini dikeluarkan oleh OJK pada tanggal16 Maret 2020 yang diawali dengan adanya stimulus dari OJK sendiri sehingga di bulanbulan awal sangat banyak terjadi restrukturisasi. Permohonan restrukturisasi banyak terjadi pada dua bulan awal hingga lebih dari 50\% permohonan diajukan. Dari bulan Maret sampai bulan Mei sudah ada 4,95 juta nasabah yang melakukan permohonan restrukturisasi senilai 458,8 triliun rupiah.

Renegosiasi utang dalam restrukturisasi kredit merupakan upaya untuk mendapatkan penyelesaian utang-utang debitur. Dalam penyelesaian utang yang dimaksudkan bukan diartikan sebagai pembayaran secara tunai dan sekaligus atas utang-utang debitur kepada kreditur, dan juga bukan diartikan sebagai renegosiasi atau perundingan untuk penghapusan atau pengurangan utang debitur, akan tetapi merupakan upaya untuk mendapatkan kebijakan bagi penyelamatan kredit sebagai suatu solusi, sehingga debitur mempunyai kesempatan untuk menata usaha dan keuangannya dan kemudian memiliki kemampuan kembali untuk membayar utang-utangnya. ${ }^{10}$

\section{Akibat Hukum Restrukturisasi Kredit Setelah Dilakukan Renegoisasi Dalam Perjanjian Kredit}

Seperti yang kita ketahui, pada masa pandemi COVID-19 memberikan dampak ke semua aspek kehidupan, terutama dalam bidang perekonomian. Selain debitur atau nasabah, Bank dalam hal ini juga merasakan dampak dari penyebaran COVID-19, dimana terjadi peningkatan risiko kredit perbankan akibat penurunan kemampuan dan kinerja debitur dalam memenuhi kewajibannya untuk membayar cicilan kredit. Di satu sisi debitur kehilangan potensi usahanya di masa seperti sekarang ini, di sisi lain kinerja perbankan terganggu karena adanya peningkatan risiko kredit. Sebagaimana termuat dalam ketentuan Penjelasan Umum POJK No. 11/2020, oleh karena adanya peningkatan risiko kredit yang berdampak pada terganggunya kinerja dan stabilitas sistem keuangan, dapat

\footnotetext{
10 Aman Sentosa, 'Renegosiasi Dan Restrukturisasi Perusahaan Dalam Upaya Penyelesaian Utang' (2000) Ius Quia Iustum Law Journal of Islamic University of Indonesia.[195 - 202].
} 
mempengaruhi pertumbuhan ekonomi juga sehingga diperlukan kebijakan yang bersifat countercyclical.

Kebijakan ini bertujuan untuk mendorong kinerja perbankan khususnya fungsi intermediasi, menjaga stabilitas sistem keuangan dan mendukung pertumbuhan ekonomi dengan memberikan perlakuan khusus terhadap kredit dalam jumlah tertentu dan kredit yang direstrukturisasi kepada debitur yang terkena dampak penyebaran COVID-19.

Pengertian mengenai restrukturisasi kredit termuat dalam ketentuan Pasal 1 angka 4 Peraturan Otoritas Jasa Keuangan Nomor 11/POJK.03/2015 Tentang Ketentuan Kehati-Hatian Dalam Rangka Stimulus Perekonomian Nasional Bagi Bank Umum yang menentukan sebagai berikut:

“Restrukturisasi kredit adalah upaya perbaikan yang dilakukan Bank dalam kegiatan perkreditan terhadap debitur yang mengalami kesulitan untuk memenuhi kewajibannya, yang dilakukan antara lain melalui:

a. penurunan suku bunga kredit;

b. perpanjangan jangka waktu kredit;

c. pengurangan tunggakan bunga kredit;

d. pengurangan tunggakan pokok kredit;

e. penambahan fasilitas kredit; dan/atau

f. konversi kredit menjadi penyertaan modal sementara".

Renegosiasi merupakan proses dalam restrukturisasi kredit. Salah satu perubahan perjanjian guna meringankan pembayaran debitur ialah dengan rescheduling atau memperpanjang periode pembayaran cicilan kredit. Yang diubah ialah klausula mengenai jangka waktu jatuh tempo yang ada di dalam perjanjian kredit sebelumnya. Perjanjian pada umumnya memiliki asas-asas untuk mendukung keabsahan suatu kontrak sehingga memiliki kekuatan hukum yang mengikat, adapun asas-asas dalam kontrak tersebut adalah sebagai berikut: ${ }^{11}$

1. Asas Kebebasan Berkontrak (freedom of contract), Asas kebebasan berkontrak dapat dianalisis dari ketentuan Pasal 1338 ayat (1) BW yang berbunyi "semua perjanjian yang dibuat secara sah berlaku sebagai undang-undang bagi

\footnotetext{
${ }^{11}$ Salim HS, Abdullah, Wiwiek Wahyuningsih, Perancangan Kontrak dan Memorandum of Understanding (Sinar Grafika 2014).[2].
} 
mereka yang membuatnya". Asas kebebasan berkontrak adalah suatu asas yang memberikan kebebasan kepada para pihak untuk: (1) membuat atau tidak membuat perjanjian; (2) mengadakan perjanjian dengan siapapun; (3) menentukan isi perjanjian, pelaksanaan, dan persyaratan; dan (4) menentukan bentuknya perjanjian, yang tertulis atau lisan.

2. Asas Pacta Sunt Servanda, Asas ini disebut dengan asas kepastian hukum. Asas ini berhubungan dengan akibat perjanjian. Asas pacta sunt servanda menggariskan bahwa hakim atau pihak ketiga harus menghormati substansi kontrak yang dibuat oleh para pihak, sebagaimana layaknya sebuah undangundang. Mereka tidak boleh melakukan intervensi terhadap substansi kontrak yang dibuat para pihak.

3. Asas konsensualisme, Asas konsensualisme ini adalah bahwa lahirnya kontrak ialah pada saat terjadinya kesepakatan. Dengan demikian, apabila tercapai kesepakatan antara para pihak, lahirlah kontrak, walaupun kontrak itu belum dilaksanakan pada saat itu. Hal ini berarti bahwa dengan tercapainya kesepakatan oleh para pihak melahirkan hak dan kewajiban bagi mereka atau biasa juga disebut bahwa kontrak tersebut sudah bersifat obligatoir, yakni melahirkan kewajiban bagi para pihak untuk memenuhi kontrak tersebut. Asas konsensualisme terdapat terdapat di dalam Pasal 1320 BW.

4. Menurut Pasal 1338 ayat (3) BW, suatu kontrak haruslah dilaksanakan dengan itikad baik (goeder trouw, bona fide). Rumusan dari Pasal 1338 ayat (3) BW tersebut mengindikasikan bahwa sebenarnya itikad baik bukan merupakan syarat sahnya suatu kontrak sebagaimana syarat yang terdapat dalam pasal 1320 BW. Itikad baik disyaratkan dalam hal "pelaksanaan" dari suatu kontrak, bukan pada "pembuatan suatu kontrak. Sebab, unsur "itikad baik" dalam hal pembuatan suatu kontrak sudah dapat dicakup oleh unsur "kausa yang diperbolehkan" dari Pasal 1320 BW tersebut.

Agar suatu klausula perjanjian dalam hal ini klausula perpanjangan periode dapat dikatakan berlaku secara sah maka dalam melakukan renegosiasi untuk perubahan perjanjian tersebut harus memenuhi syarat-syarat mengenai sahnya perjanjian itu sendiri yang diatur dalam Pasal 1320 BW, yaitu:
a. Sepakat mereka yang mengikatkan dirinya (Kesepakatan/ toestemming);
b. Kecakapan untuk membuat perikatan (Kecakapan/bekwaamheid);
c. Suatu hal tertentu (Objek tertentu/een bepaald onderwerp);
d. Suatu sebab yang diperbolehkan (Kausa/oorzaak).

Adapun syarat pertama dan syarat kedua merupakan syarat subjektif karena mengenai orang-orangnya atau subjek yang mengadakan perjanjian, sedangkan syarat ketiga dan syarat keempat merupakan syarat objektif karena mengenai perjanjiannya sendiri atau objek dari perbuatan hukum yang dilakukan itu. Tidak dipenuhinya salah satu atau lebih dari syarat-syarat sahnya perjanjian 
sebagaimana yang diatur dalam Pasal 1320 BW, baik syarat subjektif maupun syarat objektif, akan mempunyai akibat-akibat sebagai berikut: ${ }^{12}$

a. Non-eksistensi, apabila tidak ada kesepakatan maka tidak timbul perjanjian.

b. Vernietigbaar atau dapat dibatalkan, apabila kontrak tersebut lahir karena adanya cacat kehendak (wilsgebreke) atau karena ketidakcakapan (onbekwaamheid) - (Pasal 1320 BW syarat pertama dan kedua), berarti hal ini terkait dengan unsur subjektif, sehingga berakibat kontrak tersebut dapat dibatalkan; dan

c. Nietig atau batal demi hukum, apabila terdapat perjanjian yang tidak memenuhi syarat objek tertentu atau kausanya tidak diperbolehkan (Pasal 1320 BW syarat ketiga dan keempat), berarti hal ini terkait dengan unsur objektif, sehingga berakibat perjanjian tersebut batal demi hukum.

Berdasarkan penjelasan di atas, dapat diketahui bahwa syarat sahnya perjanjian ini bersifat kumulatif. Artinya seluruh persyaratan tersebut harus dipenuhi agar perjanjian itu menjadi sah, dengan konsekuensi tidak dipenuhi satu atau lebih syarat dimaksud akan menyebabkan perjanjian tersebut dapat diganggu gugat keberadaannya (batal/neitig atau dapat dibatalkan/vernietigbaar).

Kesepakatan dalam perjanjian adalah wujud dari suatu persesuaian kehendak antara dua pihak atau lebih mengenai apa yang mereka kehendaki untuk dilaksanakan, bagaimana cara melaksanakan dan kapan akan dilaksanakan, serta siapa yang harus melaksanakan. Intinya adalah para pihak saling menyatakan kehendak masing-masing untuk menutup suatu perjanjian atau pernyataan pihak yang satu "cocok" dengan pernyataan pihak yang lain. Disinilah terjadi suatu proses negosiasi, negosiasi ulang yang dilakukan dalam restrukturisasi kredit harus dilaksanakan berdasarkan asas-asas yang disebutkan di atas, selain itu renegosiasi guna mencapai kesepakatan dikatakan sah jika memenuhi persyaratan yang ada di dalam ketentuan Pasal 1320 BW. Dengan sahnya suatu perjanjian yang diubah maka klausula yang terdapat dalam perjanjian tersebut pun juga 1985).[6].

${ }^{12}$ J. H. Nieuwenhuis, Pokok-Pokok Hukum Perikatan (Fakultas Hukum Universitas Airlangga 
sah. Oleh sebab itu, pengertian sepakat dilukiskan sebagai pernyataan kehendak yang disetujui antara pihak-pihak, sehingga perubahan klausula perpanjangan periode pembayaran atau memperpanjang jangka waktu jatuh tempo pembayaran dalam restrukturisasi kredit menunjukan bahwa para pihak sepakat untuk melakukan perjanjian, yang menjadikan dasar kesepakatan kedua belah pihak untuk melakukan perjanjian dengan itikad baik tanpa adanya paksaan dari pihak manapun.

Restrukturisasi ini ditujukan untuk memenuhi prestasi debitur yang masih memiliki itikad baik dalam melakukan kewajibannya, agar debitur tersebut tidak dinyatakan wanprestasi. Seorang dikatakan lalai, apabila ia tidak memenuhi kewajibannya atau terlambat memenuhinya tetapi tidak seperti yang telah diperjanjikan. ${ }^{13}$ Wanprestasi adalah ketiadaan suatu prestasi di dalam hukum perjanjian, berartisuatuhal yang harus dilaksanakan sebagaiisi dari suatu perjanjian. Barangkali dalam bahasa Indonesia dapat dipakai istilah pelaksanaan janji untuk prestasi dan ketiadaan pelaksanaannya janji untuk wanprestasi. ${ }^{14}$ Apabila debitur "karena kesalahannya" tidak melaksanakan apa yang diperjanjikan, maka debitur itu wanprestasi atau cidera janji. Kata karena salahnya sangat penting, oleh karena debitur tidak melaksanakan prestasi yang diperjanjikan sama sekali bukan karena salahnya. Wanprestasi itu dapat berupa perbuatan:

1. Sama sekali tidak memenuhi prestasi, tidak memenuhi prestasi sama sekali, sehubungan dengan debitur yang tidak memenuhi prestasi maka dikatakan debitur tidak memenuhi prestasi sama sekali. Dalam hal ini pemenuhan prestasi bagi para pihak dalam sewa-menyewa, tidak boleh salah satu pihak melanggar dari isi perjanjian keduanya. Apabila telah diperjanjikan maka harus disepakati, adapun terkait dengan kontrak perpanjangan otomatis tersebut juga harus dilakukan kecuali para pihak menginginkan perubahan.

2. Prestasi yang dilakukan tidak sempurna, memenuhi prestasi tetapi tidak sesuai atau keliru, debitur yang memenuhi prestasi tapi keliru, apabila prestasi yang keliru tersebut tidak dapat diperbaiki lagi maka debitur dikatakan tidak memenuhi prestasi sama sekali.

3. Terlambat memenuhi prestasi, memenuhi prestasi tetapi tidak tepat waktunya, apabila prestasi debitur masih dapat diharapkan pemenuhannya,

${ }^{13}$ R. Subekti, Kitab Undang-Undang Hukum Perdata (Arga Printing 2007).[146].

${ }^{14}$ Wirjono Prodjodikoro, Asas-asas Hukum Perjanjian (Sumur Pustaka 2012).[17]. 
maka debitur dianggap memenuhi prestasi tetapi tidak tepat waktu, sehingga dapat dikatakan wanprestasi. Dalam hal ini apabila kontrak sewa menyewa tersebut telah melarang untuk melakukan pembayaran dengan waktu yang ditentukan, tetapi pembayaran tersebut dilakukan pembayaran dengan waktu yang tidak sesuai.

4. Melakukan apa yang dalam perjanjian dilarang untuk dilakukan. ${ }^{15}$

Apabila melihat kasus terkait kredit macet atau debitur yang tidak mampu melaksanakan kewajibannya membayar cicilan kredit, maka perbuatan debitur tersebut merujuk pada perbuatan poin tiga, yaitu terlambat memenuhi prestasi dengan alasan pandemi COVID-19. Debitur yang terlambat memenuhi prestasi berarti dapat memenuhi prestasi namun tidak sesuai dengan jangka waktu dalam perjanjian. Melihat hal ini, debitur dapat dikatakan wanprestasi, akan tetapi jika dilihat alasan terlambat dalam memenuhi prestasi itu adalah alasan force majeure karena pandemi COVID-19 dapat dikualifikasikan sebagai force majeure, sehingga debitur dapat terbebas dari tuntutan penggantian biaya, rugi dan bunga, sebagaimana diatur dalam ketentuan Pasal 1244 BW dan Pasal 1245 BW.

Oleh karena itu, agar tidak terjadinya wanprestasi, dikeluarkannya kebijakan restrukturisasi kredit sebagai upaya Bank atau lembaga pembiayaan lain terhadap debitur dengan memberikan keringanan pembayaran cicilan kredit atau pinjaman. Restrukturisasi kredit dilakukan dengan cara renegosiasi perjanjian kredit yang sudah ada sehingga perjanjian yang baru akan menggantikan perjanjian yang lama, akibatnya terjadi perubahan pada syarat-syarat atau ketentuan-ketentuan di dalamnya, misalnya jangka waktu jatuh tempo diperpanjang, maka dengan begitu tidaklah dapat dikatakan wanprestasi. Renegosiasi kredit yang dimaksudkan untuk mengkondisikan kembali perjanjian hubungan antara debitur dengan kreditur, sehingga tercipta suatu keadaan baru yang diperjanjikan haruslah dibuat sedemikian rupa dengan memperhatikan tuntutan hukum yang ada agar perjanjian kredit yang baru atau kesepakatan baru mengenai penyelesaian kredit debitur memiliki keabsahan dan konsekuensi hukum bagi para pihak. Unsur kesepakatan dalam renegosiasi kredit adalah terdapatnya kesepakatan baru 
mengenai cara penyelesaian utang-utang debitur dalam berbagai kebijaksanaan ataupun kemudahan yang diberikan kreditur dengan mempertimbangkan keadaan dan kemampuan debitur. ${ }^{16}$

\section{Kesimpulan}

Renegosiasi dalam perjanjian adalah upaya untuk merundingkan kembali cara-cara penyelesaian atau pengembalian utang debitur yang didasarkan pada perjanjian utang seluruhnya yang ternyata tidak dapat dilaksanakan tepat waktu. Tetapi sejak dinyatakan pandemi COVID-19 sejak bulan Maret 2020 hingga saat ini, sangat sulit untuk menilai kemampuan dan prospek debitur selama pandemi. Restrukturisasi utang dapat dilakukan apabila bisnis debitur masih memiliki prospek usaha yang baik untuk mampu melunasi utang-utangnya, para kreditur akan memperoleh pelunasan utang yang jumlahnya lebih besar melalui restrukturisasi utang daripada apabila perseroan dinyatakan pailit, dan syaratsyarat utang berdasarkan restrukturisasi utang lebih menguntungkan bagi para kreditur daripada sebelum dilakukan restrukturisasi. Debitur harus mampu memenuhi tiga syarat tersebut, apabila akan melakukan restrukturisasi kredit dalam renegosiasi perjanjian kredit saat pandemi.

Huruf g dalam Pasal 5 ayat (1) Undang-Undang Wabah Penyakit Menular menyebutkan bahwa penanggulangan lainnya yang harus dilakukan pemerintah, dalam hal ini dapat diartikan bahwa upaya penanggulangan lain-lain dapat juga penanggulangan terhadap ekonomi, salah satu yang terdampak saat wabah adalah ekonomi, khususnya kemampuan seseorang dalam melakukan kewajibannya dalam pembayaran utang. Tanggungjawab pemerintah dalam melakukan penanggulangan wabah pada sektor ekonomi salah satunya dengan mengeluarkan Peraturan Otoritas Jasa Keuangan Nomor 11/POJK.03/2020 Tentang Stimulus Perekonomian Nasional Sebagai Kebijakan Countercyclical Dampak Penyebaran Coronavirus Disease 2019 yang telah diperpanjang dengan

${ }^{16}$ Aman Sentosa, Loc.Cit. 
dikeluarkannya POJK Nomor 48 /POJK.03/2020 Tentang Perubahan Atas Peraturan Otoritas Jasa Keuangan Nomor 11/POJK.03/2020 Tentang Stimulus Perekonomian Nasional Sebagai Kebijakan Countercyclical Dampak Penyebaran Coronavirus Disease 2019, peraturan ini dikeluarkan pemerintah melalui OJK untuk memberikan kemudahan bagi debitur dalam melakukan pembayaran utang dan memberikan jaminan kepada kreditur agar debitur dapat memenuhi kewajibannya sekalipun waktunya tidak sesuai dengan perjanjian awal sehingga dilakukan restrukturisasi kredit. Restrukturisasi merupakan renegosiasi kredit yang dimaksudkan untuk mengkondisikan kembali perjanjian hubungan antara debitur dengan kreditur. sehingga tercipta suatu keadaan baru yang diperjanjikan haruslah dibuat sedemikian rupa dengan memperhatikan tuntutan hukum yang ada agar perjanjian kredit yang baru atau kesepakatan baru mengenai penyelesaian kredit, debitur memiliki keabsahan dan konsekuensi hukum bagi para pihak, sehingga meminimalisir adanya wanprestasi oleh debitur dan hak-hak kreditur dalam pemenuhan pembayaran tersebut juga mendapatkan kepastian.

\section{Daftar Bacaan}

\section{Buku}

Agus Yudha Hernoko, Hukum Perjanjian Asas Proporsionalitas Dalam Kontrak Komersial (Kencana 2014).

Ahmadi Miru, Hukum Kontrak \& Perancangan Kontrak (Rajawali Pers 2010).

Edi Putra Tje'Aman, Kredit PerBankan Suatu Tinjauan Yuridis (Liberty 1986).

J. H. Nieuwenhuis, Pokok-Pokok Hukum Perikatan (Fakultas Hukum Universitas Airlangga 1985).

Mariam Darus Badrulzaman, Kitab Undang-Undang Hukum Perdata Buku III Hukum Perikatan Dengan Penjelasan (Alumni 1996).

Salim HS, Abdullah, Wiwiek Wahyuningsih, Perancangan Kontrak dan Memorandum of Understanding (Sinar Grafika 2014).

Subekti, Kitab Undang-Undang Hukum Perdata (Arga Printing 2007). 
Pokok-pokok Hukum Perdata (Intermasa 1985).

Wirjono Prodjodikoro, Asas-asas Hukum Perjanjian (Sumur Pustaka 2012).

\section{Jurnal}

Aman Sentosa, 'Renegosiasi Dan Restrukturisasi Perusahaan Dalam Upaya Penyelesaian Utang' (2000) Ius Quia Iustum Law Journal of Islamic University of Indonesia.

\section{Perundang-undangan}

Burgerlijk Wetboek (Stb. No.23 tahun 1847 tanggal 30 April 1847).

Undang-Undang Republik Indonesia Nomor 4 Tahun 1984 tentang Wabah Penyakit Menular (Lembaran Negara Republik Indonesia Tahun 1984 Nomor 20, Tambahan Lembaran Negara Republik Indonesia Nomor 3273).

Undang-Undang Republik Indonesia Nomor 24 Tahun 2007 tentang Penanggulangan Bencana (Lembaran Negara Republik Indonesia Tahun 2007 Nomor 66, Tambahan Lembaran Negara Republik Indonesia Nomor 4723).

Peraturan Pemerintah Republik Indonesia Nomor 21 Tahun 2020 tentang Pembatasan Sosial Berskala Besar Dalam Rangka Percepatan Penanganan Corona Virus Disease 2019 (COVID-19).

Keputusan Presiden Republik Indonesia Nomor 11 Tahun 2020 tentang Penetapan Kedaruratan Kesehatan Masyarakat Corona Virus Disease 2019 (COVID-19).

Keputusan Presiden Republik Indonesia Nomor 12 Tahun 2020 tentang Penetapan Bencana Non Alam Penyebaran Corona Virus Disease 2019 (COVID-19) Sebagai Bencana Nasional.

Peraturan Menteri Kesehatan Republik Indonesia Nomor 9 Tahun 2020 tentang Pedoman Pembatasan Sosial Berskala Besar Dalam Rangka Percepatan Penanganan Corona Virus Disease 2019 (COVID-19).

Peraturan Otoritas Jasa Keuangan Republik Indonesia Nomor 48/POJK.03/2020 Tentang Perubahan Atas Peraturan Otoritas Jasa Keuangan Republik Indonesia Nomor 11/POJK.03/2020 Tentang Stimulus Perekonomian Nasional Sebagai Kebijakan Countercylical Dampak Penyebaran Corona Virus Disease 2019.

How to cite: Tamara Teguh, Faisal Kurniawan dan Bambang Sugeng A.S., 'Keabsahan Klausula Perpanjangan Periode dalam Restrukturisasi Kredit Akibat Pandemi Covid-19' (2021) Vol. 4 No. 2 Notaire. 